\title{
CSR AS A PREREQuisite OF CONSUMER BEHAVIOR IN A TRANSITIONAL ECONOMY
}

\author{
OMAZIC M. A.
}

\begin{abstract}
A large number of companies around the world are increasingly talking about corporate social responsibility as a concept that ensures business success, but also the sustainable development of society in general. Although initially set up as a voluntary activity, today corporate social responsibility (CSR) is treated as an important and indispensable social mechanism. Therefore, for many modern companies it is no longer enough just to produce quality products and provide distinctive services to its customers, but they should take into account the wider social and environmental consequences of their actions. Considering that the concept and phenomena of CSR can contribute to long-term sustainability of companies, the goal of this paper is to explain the concept of CSR and its impact on consumer behavior in the sports retail industry in a transitional economy. The authors also aimed to examine whether consumers in the sports industry know how the companies they are buying from behave, whether they consider social responsibility as an important factor for selection of sports products, and are they willing to punish or reward socially (ir)responsible companies.
\end{abstract}

Keywords: corporate social responsibility (CSR), consumer behavior, sports industy
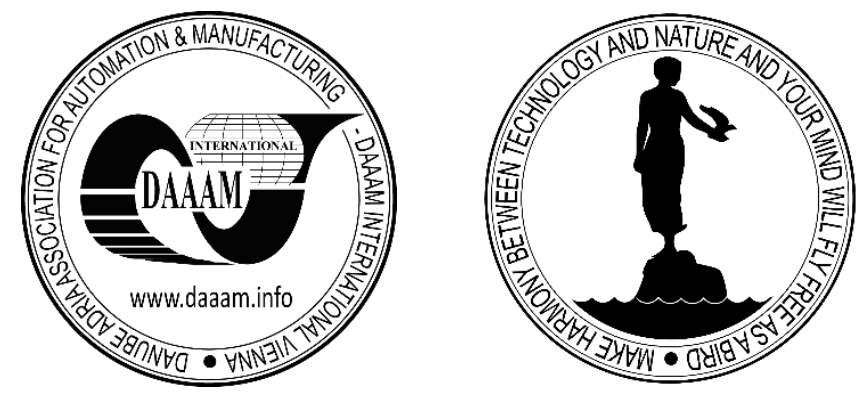

Authors' data: Univ. Prof. dr. sc. Omazic, M[islav] A[nte]; Faculty of Economics and Business, University of Zagreb, Trg J. F. Kennedya 6, 10000, Zagreb, Croatia, momazic1@efzg.hr

This Publication has to be referred as: Omazic, M[islav] A[nte] (2016). Csr as a Prerequisite of Consumer Behavior in a Transitional Economy, Chapter 17 in DAAAM International Scientific Book 2016, pp.183-196, B. Katalinic (Ed.), Published by DAAAM International, ISBN 978-3-902734-09-9, ISSN 1726-9687, Vienna, Austria DOI: $10.2507 /$ daaam.scibook.2016.17 
Omazic, M. A.: Csr as a Prerequisite of Consumer Behavior in a Transitional Econo...

\section{Introduction}

The concept of corporate social responsibility (CSR) is wide and has a multitude of forms, scopes and manners of implementation. It centered around the growing belief that modern companies have more responsibility to their role in society, and stronger pressures of civil society, technological progress, resource gaps and other trends are forcing companies to integrate it into all elements of business (Garriga, Melé, 2004). Corporate social responsibility is not a static and linear concept, but an ongoing process of negotiation and redefining the possible (Omazic, 2008). The results that responsibility covers are changing over time in relation to the cultural and political aspects. Furthermore, the focus of this concept is the idea that reflects the social imperatives and social consequences of business success. Therefore, it consists of clearly articulated and communicated principles and practices of companies, which reflect social responsibility (Matten, Moon, 2008). Three basic directions od CSR assessment are characterized as: (1) stakeholder orientation (CSR is perceived as a response to the specific needs mostly of the external stakeholders), (2) navigation of performance (link between external expectations and CSR activities of the company, with a focus on measuring the effectiveness of such activities) and (3) orientation towards motivation (assessing extrinsic reasons for CSR engagement in companies or intrinsic justification for the improvement of certain terms of its obligations and responsibilities)

Companies with their activities should adopt and apply the four dimensions of social responsibility - economic (achieving economic and financial results, business expansion and growth of the organization), social (respecting the needs of the community and its members), ecological (care about environment and optimal use of limited natural resources which ensures the long-term sustainable development of the organization and society) and ethical (moral behavior in accordance with the social values of the community and culture) (Banerjee, 2007; Omazic, 2008). However, social responsibility as a concept of management is not only focused on the balance of economic, environmental, social and ethical dimensions of business activities, but also on the repositioning of the business world with respect to the needs of all humanity, and is subject to formal or informal pressure of stakeholders, the values of the society and community in which the company operates, and the strategy in which the company has integrated its responsibility in daily operations (Omazic, 2008).

Being responsible is not unchanging, it is a constant state established by performance of business activities in practice and how they are integrated into business (Fryzel, 2011). Also, it is often described as discretionary corporate activity with the intent to improve the social well-being on a voluntary level, going beyond the interests of the company or requirements prescribed by law (Barnett, 2007). Every company should have the right to decide which areas to give greater attention to, in relation to their own strategic objectives, sources of risk and business opportunities that contribute to the establishment of competitiveness by improving reputation, reducing operational costs, monitoring of industrial competitors, satisfying clients' needs, motivating and 
attracting the best employees, risk management and access to cheaper capital. Activities associated with the CSR usually represent the efforts of companies to cover a wider range of social problems than it would have done in the course of their normal pursuits of profit (Vogel, 2015), and to integrate the changing expectations of society into their risk change and opportunities management, as well as ways these business practices meet the needs of the business environment. It is applicable to companies of all sizes, although most studies have examined large companies due to the fact that their influence is the most evident, and their power the greatest.

Full integration of CSR in accordance with sustainability is one of the possible solutions in order to face the problems of modern societies which are increasingly characterized by global economic crisis, the loss of public confidence, criticism and debate about the role of business in the current context (Omazic, 2008) and therefore it is necessary for the organization to accept it as a basis for strategic development in good faith and to act in accordance with the constant social changes of norms and rules (Osmanagic Bedenik, Labas, 2011).

\section{Theoretical rules of consumer behaviour}

The pace of change in global business, as well as, the increasing reliance on networking, sharing and creating strategic relationships and less existence of any visible borders, and with rapid technological advances pose new challenges for marketing in both the scientific and in the applicative sense. In addition to meeting the goals of individuals and organizations, there is a need to address the wider social objectives, ie. Both profit and non-profit organizations have to be socially responsible and environmentally and ethically conscious with their activities. However, although the promotion of ethical corporate behavior has become increasingly important to more and more companies, the question is whether it is relevant to the consumers, ie. Wheather this new concern for corporate ethics really help companies at the market. Therefore, many managers who consider issues such as does the impression consumers have about the ethics of companies influence their decision to purchase and do consumers notice when company becomes extremely concerned about corporate ethics (Creyer, Ross, 1997).

After the definition of social responsibility from the corporate side, it is necessary to define the impact of socially responsible behavior of the companies on consumer behavior and the emergence of socially responsible consumers. Webster (Mohr et al., 2001) provides the most comprehensive definition of socially conscious consumer as the consumer who takes into account the public consequences of their private purchases or attempts to use their purchasing power for social change. Therefore, socially responsible consumer behavior occurs when a person base acquisition, use and disposal of products in order to minimize or eliminate any adverse effects and maximize the long-term positive impact on society. This behavior requires the involvement of the social responsibility of business as one of the criteria that affects the person's consumption patterns. Socially responsible consumer would thus avoid the purchase of 
products that harm and actively search for products that help the society. Furthermore, the idea that consumer have the power to influence corporate behavior may include those who are at an early stage of readiness, support their positive attitudes towards responsible companies providing arguments against some of their fears, and pull them into the direction of socially responsible behavior. Finally, considering that there is a group of consumers to whom socially responsible corporate behavior is important, and that group is growing, the rules should be designed to discourage abuse of the marketing communication of corporate social responsibility (Mohr et al., 2001).

The study of consumer behavior has implications for society as a whole since knowing the factors and processes that affect it can serve as the basis for guiding the behavior. It is a young scientific discipline, and the first book in the field appears in 1960. According to the American Marketing Association (AMA) consumer behavior is defined as the dynamic interaction of cognition and environmental factors, which result in behavioral and change of the consumer's aspects of life (Schiffman \& Wisenblit, 2015). It contains a series of psychological and physical activity undertaken by an individual or household in the selection process, buying and consuming products and/or services.

Interest in consumer behavior and its application have numerous stakeholders such as the scientific community, marketing professionals, educators on consumer behavior, an organization that cares about the protection of consumers and society as a whole, with different social policy objectives. There are three fundamental objectives to study the consumer behavior: (1) understanding and predicting consumer behavior, (2) adopting regulatory policies to protect consumers in the society and (3) detection of cause-effect relationship that determines informing the consumers and educating young people. Three main phases in consumer behavior can be emphasized: (1) phase of buying in which the factors affecting the selection of products and services are considered and most of the research of consumer behavior deal with exactly this issue, (2) the consumption phase, which deals with the process of consumption, evaluation and acquisition of experience that has the meaning for the future behavior and (3) the phase of disposal which includes consumer's decision what to do with used products or what is left of them. Also, in the study of consumer behavior, marketing experts start from the five basic rules which say that: (1) the consumer is sovereign, and cannot be manipulated, but can be adjusted, (2) the motives of his/hers behavior can be identified, (3) his/hers behavior can be influenced by the elements of the marketing mix which can be adapted to their needs, (4) impact on him/her should be socially acceptable and (5) consumer behavior is a dynamic process that is affected by a number of trends (eg. the trend of healthy living, environmental protection etc.) and the marketing experts need to monitor changes in the environment and consumers that will lead to changes in behavior of the target segment (Schiffman \& Wisenblit, 2015). 


\section{The relationship between corporate social responsibility and consumer behavior}

Socially responsible activities gradually become a leading issue in business of the companies that are taking the whole range of initiatives aimed at creating a sense of business in a socially responsible manner. Since, corporate social responsibility is becoming an important issue among the stakeholders in the corporate world, that enthusiasm begins to reflect in the marketing literature as well (Kotler \& Lee, 2005; Sen \& Bhattacharya, 2001). Studies have focused on different topics, such as social responsibility among marketing professionals or consumer reaction and response to corporate social responsibility (Sen et al., 2006). One reason for the growing interest in corporate social responsibility is the impact of consumer behavior at a time when consumers demand more from companies than just high-quality products or low prices, and more and more scientific research is directed in such a direction and testifies that corporate social responsibility has a positive impact on evaluation of products and companies, as well as consumers intent to purchase (Sen \& Bhattacharya, 2001; Ellen et al., 2006; Abdeen et al., 2016; Mohr \& Webb, 2005; Wongpitch et al., 2016). Consumers expect companies to demonstrate compatibility with social values as part of the contribution to the community and can evaluate the company on the grounds whether it is behaving in a manner consistent with supporting the welfare of the community and the society (Marin et al., 2008). In addition, there are numerous studies of corporate social responsibility, corporate ethics and social sponsorships that suggest a link between social initiatives and improved financial performance, as well as studies showing a link between social initiatives and positive emotional, cognitive and behavioral responses of consumers (Omazic, 2008; Osmanagic Bedenik, Labas, 2011). Specifically, the research are looking for a relationship between social research and price, perceived quality, corporate attitudes and intentions of buying (Becker-Olsen et al., 2006).CSR should therefore create more added value for the consumer who is willing to pay more for products that are produced in socially responsible companies (Mohr \& Webb, 2005).

The positive link between CSR and sponsorship of consumers can also lead to the realization among managers that CSR is not just an ethical/ideological imperative, but also economical in today's market (Jones et al., 2007). Questions of consumer awareness of corporate social responsibility are mainly related to that whether consumers perceive CSR activities during the purchase (Pomering \& Dolnicar, 2008) and could its deficiency cause the lack of sensitivity among consumers and explain why CSR is not taken into account in evaluating the company and its products. If consumers are aware of CSR and better understand the activities, they are likely to show a positive attitude towards supporting the company and its products (Tian et al., 2011) and CSR will play an important role in the routine behavior of consumers over economic and "rational" considerations such as product characteristics (Klein \& Dawar, 2004; Marin et al., 2008;). Also, it is often referred that socially responsible activities may affect the intention to purchase (Singh et al., 2008) and that they can be 
associated to the fact whether ethical behavior of the company goes beyond customer expectations (Creyer, Ross, 1997). Brown and Dacin (Lii \& Lee, 2012) found that corporate links that include corporate capability and corporate social responsibility, influence the evaluation of the product and the entire company by the customer and the CSR initiatives are well established in the literature in the field of marketing as they are affecting the diversity of outcomes, including the image or reputation of the company, product assessment, intention to purchase and market value of companies. A common example of csr activities to which consumers positively react refers to the phenomena of Cause Related Marketing (CRM). CRM refers to activities in which corporations promise to give a certain portion of their margin earned, to a social cause, a charity or other forms of non profit organizations (Nan \& Heo, 2007). The way consumers respond to such activities relates to both from their positive change in the overall attitude to the company, but also to the willingness to purchase its products/services. Prior empirical research has shown a positive change in the way consumers view companies that engage in CRM activities (Webb \& Mohr, 1998). Also, earlier scholars have shown empirical evidence of an increase of willingness to purchase more of such a company's products/services (Smith \& Alcorn, 1991).

Despite these trends and interests, the value of CSR is vigorously debated in today's market conditions. Academic research of consumer reactions to CSR reveal effects favoring such undertakings at the range of cognitive and affective (beliefs, attitudes, identification) and behavioral (loyalty, even during the crisis) results (Sen et al., 2006). Many consumers are willing to put pressure on companies to behave socially responsible by boycotting products and express their socially responsible concerns by ethical purchasing (Podnar \& Golub, 2007). However, the results of research in this area are sometimes contrasting considering that, although according to numerous studies social responsibility has been listed as one of the key factors that influence the company or brand loyalty, in others, CSR is far away from the dominant criterion in decisions on purchase among consumers. Often evidence suggest that the traditional criteria such as price, quality, and knowledge of the brand are still the most important selection criteria because consumers are buying for personal reasons rather than social (Sen \& Bhattacharya, 2001; Carrigan \& Attalla, 2001).

Furthermore, while the study of social responsibility grew dramatically general management and organizational behavior literature, the concept has only recently appeared within the context of sports management (Bradish \& Cronin, 2009; Godfrey, 2009). According to Walker and Kent (2009) the sports industry is different from other contexts due to the fact that it has many characteristics that are distinct from other business segments. These characteristics refer to things like the popularity of athletes associated with a particular brand, the link between sports teams and local communities or the level of emotion many consumers have towards specific sports brands. However, it soon becomes evident that corporate social responsibility is becoming very important in this segment, too. For example, FIFA (International federation of association football) has made significant investments related to social responsibility - donating more than $40 \%$ of their income directly to socially useful activities (FIFA, 2016). The 
UEFA approach to social responsibility is carefully structured and designed to both create and retain long-term benefits for society through football (UEFA, 2016). In a report called "Community and Social Responsibility" over 60 European football clubs (including famous football clubs such as Real Madrid, Barcelona, Milan, Inter, Chelsea, Manchester United, Arsenal etc.) explained how they run different CSR initiatives in their communities (UEFA, 2016). NFL and NBA partnership with the United Way and Read to Achieve, are just two of the many humanitarian and educational initiatives involving sports leagues (United Way, 2016). Nike Fair Labor Standards Act promotes healthy global labor practices and Nike executives Mark Parker and Charlie Denson state that social responsibility caused their organization to take a good look at their business model and understand the impact of the company on the world around it (Nike, 2016).

However, viewed from an empirical an theoretical perspective, we lack knowledge on two main aspects: the motives behind socially responsible activities and the overall benefits that can occur for such organizations. A number of scholars have argued that CSR is useful at improving financial performance of organizations resulting in higher profits and public support which may in turn consolidate profits (Orlitzky et al., 2003; Weber, 2008; Walker \& Kent, 2009; Jain et al., 2016). Also, if we focus on the context of the sports industry, where the cultivation of emotional connection with the organizations is critical, CSR can provide a secondary value to the organization beyond those that can be seen in other industries.

A number of factors led to the growing importance of corporate social responsibility of sports organizations (Lau et al., 2004; Walker \& Kent, 2009). First, the omnipresence of sport has led sports organizations to become influential members of the global community, especially because they have become big business. Second, sports organizations are faced with consumers who are increasingly aware of the social aspects of corporate policy. While the emphasis of corporate social responsibility initially included issues such as transparency, accountability and employee satisfaction, attention now shifts to the role of sports organizations in the society. Sports industry is characterized as a lens through which can be seen the larger perspective of social symbolism, identification, community and sociability (Walker \& Kent, 2009). As such, the emotional component of consumer interest in the sport provides significant opportunities for the study of the social responsibility of business and provides researchers the opportunity to examine socially responsible initiatives that may be unique in the sports industry. Therefore, although it is important to understand the factors that influence how decision makers respond to an ethical dilemma, it is equally important to understand how consumers interpret and react to the results of such corporate decisions and current research examines precisely the expectations that consumers have of corporate behavior in the field of sports industry. 
Omazic, M. A.: Csr as a Prerequisite of Consumer Behavior in a Transitional Econo...

\section{The empirical study of the impact of corporate social responsibility on consumer behavior}

In order to assess the impact of CSR on consumer behavior while buying sports products, a quantitative empirical study among athletes in the field of functional fitness in Croatia was conducted.

The main objectives were to : preliminary examine whether consumers of sports goods in Croatia are aware of CSR activities of the company from which they buy; to determine whether consumers of sports goods are loyal to one brand of products; to determine the importance of CSR in the selection of sports products among consumers in the field of functional fitness in Croatia and to examine would consumers in the field of functional fitness in Croatia pay more for the product developed in the companies that behave socially responsible.

For the purposes of the primary data collection an online questionnaire with 14 closed questions was designed and used. Empirical research was conducted in February 2014, and the link to the questionnaire was sent to members of the functional fitness group in Zagreb. Conducted survey resulted in the return of 107 correctly completed questionnaires, or the rate of return of $42.46 \%$,

54 participants in the survey were male (50.5\%) and 53 female (49.5\%) with age ranging from 20-54 years (Fig. 1).

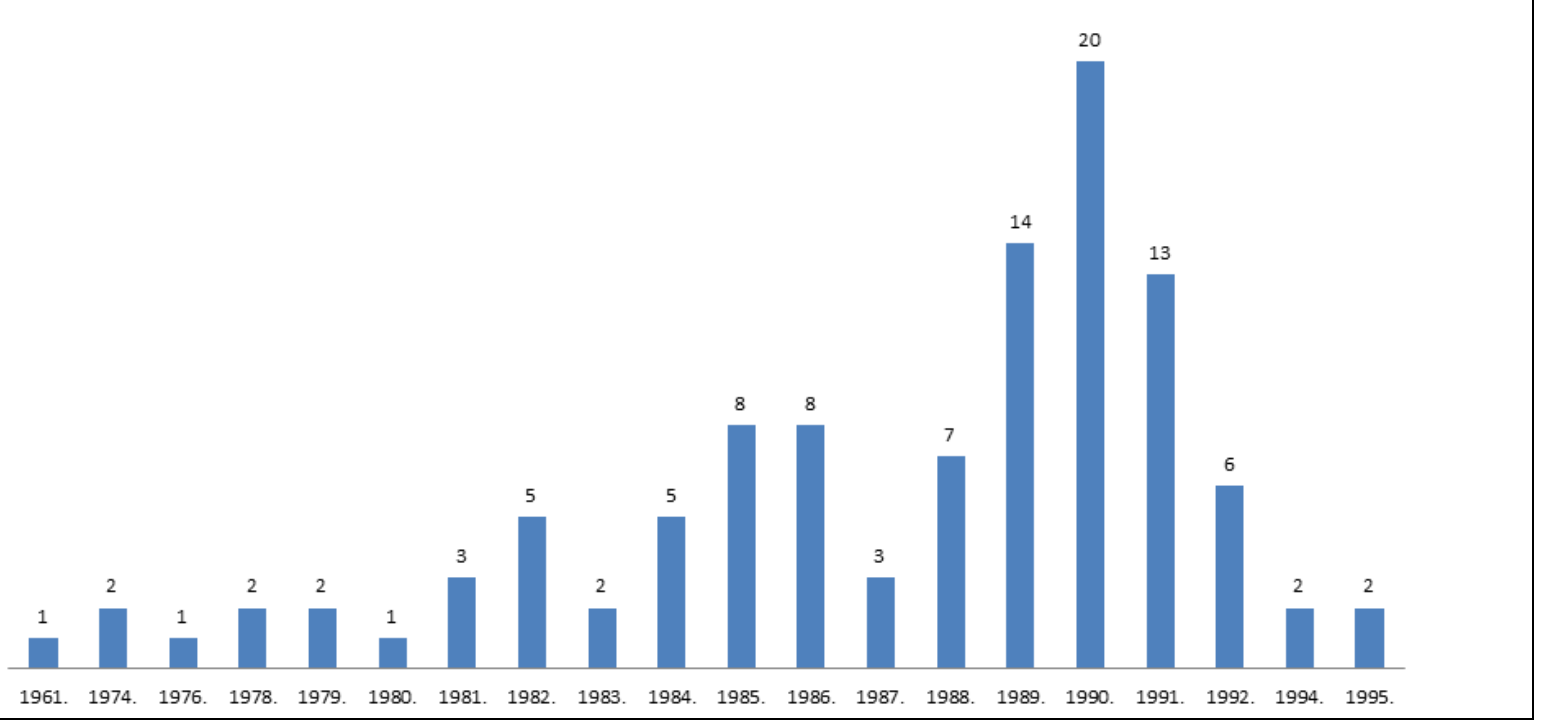

Fig. 1. The range of respondent's age

When asked to describe their current physical condition, 17 respondents selected excellent (15.9\%), 58 very good (54.2\%), 27 well (26.2\%), four considered that their physical condition is poor (3.7\%) and one respondent believes his/hers physical condition very low $(0.9 \%)$. In addition, three respondents exercise several times a day few days a week (2.8\%), 35 of them exercise five or more times a week $(32.7 \%), 43$ 
between three and five times a week $(40.2 \%)$ and 26 respondents exercise less than three times a week $(24.3 \%)$.

Most respondents buy sports products only few times a year $(43 \%$, or 46 respondents), 36 respondents (33.6\%) every couple of months, 19 respondents (17.8\%) once per month and six (5.6\%) respondents few times per month. Monthly, respondents allocate mostly less than 150 kuna on average for sports products (53.3\%), 25.4\% 150300 kuna, $17.8 \%$ 300-600 kuna, and 3.7\% more than 600 kuna. Most purchases include sportswear and footwear (42.1\%), followed by food supplements $(32 \%)$, cosmetics $(10.1 \%)$, supplements $(9.6 \%)$, machinery and equipment for training (5.6\%) and only one respondent stated that he/she buys other sports products $(0.6 \%)$, namely books.

Of all the respondents, $32.7 \%$ is choosing always the same brand of sports products, while $67.3 \%$ is not faithful to brands, 81 respondents $(75.7 \%)$ studies the properties of products such as composition or country of origin before they buy sports product, while $24.3 \%$ is not familiar with the properties of the product they choose. Further, knowledge about the corporate social responsibility of company from which they buy has only 29 respondents $(27.1 \%)$, while 78 (72.9\%) do not know how company operates.

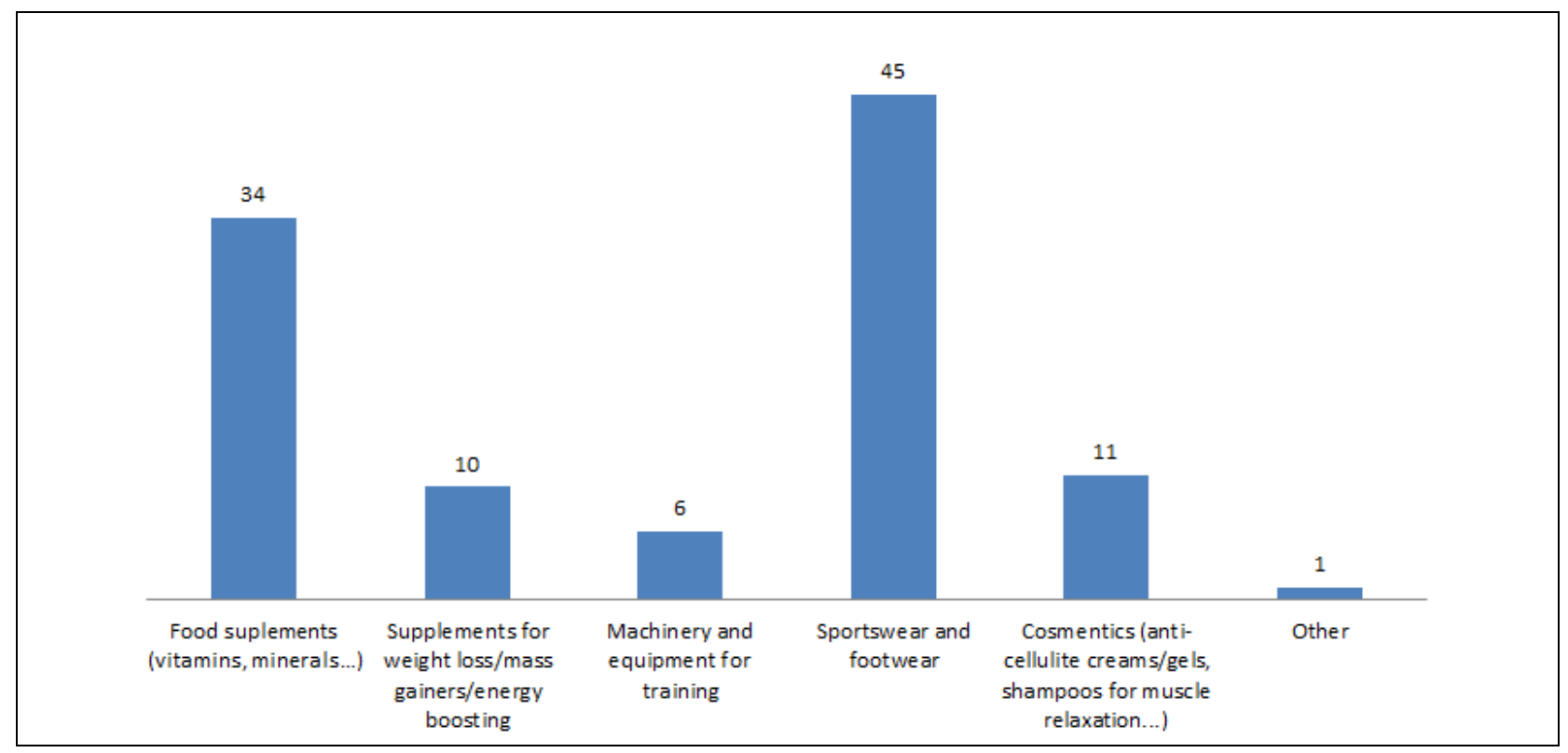

Fig. 2 Categories of sport's products

Respondents as the most important factor for choosing a sports product selected quality $(64.75 \%)$, then price $(23.81 \%)$, brand $(5.71 \%)$, availability $(4.78 \%)$ and at the end corporate social responsibility $(0.95 \%)$.

However, if the respondents were aware that the sports product was created by socially irresponsible business (eg. child labor, animal testing, lack of responsibility towards the environment), 32 of them (29.9\%) would not have given up his/hers purchases, however, 75 respondents $(70.1 \%)$ would sought for another product. Also, if their favorite brand of sports products would be made in a socially irresponsible manner, 58 respondents $(54.2 \%)$ would seek for sports product of another brand. 
Omazic, M. A.: Csr as a Prerequisite of Consumer Behavior in a Transitional Econo...

Finally, 66 respondents $(61.7 \%)$ would pay more money to buy the product produced in a socially responsible manner.

From the results obtained by empirical research follows a number of implications both for the members of the academic community and practitioners in the field. Given the fact that the initiative of corporate social responsibility is still not sufficiently recognized, but consumers in the field of functional fitness in Croatia showed interest in performing socially responsible purchasing and are willing to spend more money for products that are produced in a socially responsible manner, and since they are not aware of the scope of CSR activities of the company from which they buy sports products, managers should put the emphasis on the consumer's ability to adequately assess socially responsible programs of companies and promote these activities as a potentially powerful source of building organizational reputation. As in the evaluation of behavior of companies, many consumers may not be fully aware of the width of the activities in which the company may be included (i.e. the relationship with employees, environmental initiatives and/or activities for human rights), companies in the field of sports industry should find an adequate way to approach the consumers and raise their awareness about their CSR activities. For example, companies such as Puma, Reebok or Nike already publish annual reports on social responsibility of business or corporate sustainability, which should become the rule rather than the exception for all companies in this industry.

Also, due to the limitations of this study, which primarily examined consumer attitudes, but not their actual behavior when purchasing, which may differ, for more objective data to be obtained, in the future should be carried out an actual test of consumer behavior in the phase of buying sports products, as well as the measuring instrument expended with specific examples and situations where consumers need to act.

\section{Conclusion}

Although the relationship between CSR and consumer behavior is not a new phenomenon, this study provides insights on the specificities of this relationship within two new contexts: the sports industry and transitional economies. Although CSR in Croatia is still not sufficiently recognized, consumers within the sports industry have emphasized on the importance of purchasing responsibly. This empirical study this shows how CSR is becoming increasingly popular in Croatia and within the context of sports goods consumption. However, Croatian consumers are still not aware of the scope of CSR activities from the companies that they purchase from. This provides practical implications in a sense that companies should find new ways through which they should improve the way they articulate the CSR activities to their consumers.

The introduction of CSR into companies is a continuous process and it is necessary to invest a great effort to improve activities, as well as communicating them to consumers. The Croatian context implies how social responsibility of businesses should be seen in the context of transition in general, taking into account the legacy of 
socialism in which private business and social responsibility were seen as two opposing terms. Although the transition period is coming to an end (in economic terms), Croatian consumers are still in the process of accepting free market values, while the relevant public authorities and companies still do not see the benefits CSR can bring to them. Therefore, by learning from the example of the sports industry, Croatian companies implementing CSR should, by attracting socially aware consumers, use their CSR activities as a source of competitive advantage.

\section{References}

Abdeen, A.; Rajah, E. \& Gaur, S. S. (2016). Consumers ' beliefs about firm's CSR initiatives and their purchase behaviour, Marketing Intelligence \& Planning, Vol. 34, No. 1, pg. 2-18

Banerjee, S. B. (2007). Corporate Social Responsibility: The Good, The bad and the Ugly. Edward Elgar Publishing Limited, ISBN: 978-1-84542-976-8, Cheltenham Barnett, M. L. (2007). Stakeholder Influence Capacity and the Variability of Financial Returns to Corporate Social Responsibility. Academy of Management Review, Vol. 32, No. 3, pg. 794-816

Basu, K. \& Palazzo, G. (2008). Corporate Social Responsibility: A Process Model of Sensemaking. Academy of Management Review, Vol. 33, No. 1, pg. 122-136

Becker-Olsen, K. L.; Cudmore, B. A. \& Hill, R. P. (2006). The impact of perceived corporate social responsibility on consumer behavior, Journal of Business Research, Vol. 59, No. 1, pg. 46-53

Bradish, C. \& Cronin, J. J. (2009). Introduction Corporate Social Responsibility in Sport, Journal of Sport Management, Vol. 23, No. 6, pg. 691-697

Carrigan, M. \& Attalla, A. (2001). The myth of the ethical consumer - do ethics matter in purchase behaviour, Journal of Consumer Marketing, Vol. 18, No. 7, pg. 560-578

Chen, B.; Chen, H. M.-H.; Tai, P.-N. \& Hsiung, W.-C. (2015). Constructing the Corporate Social Responsibility Indicators of Professional Sport Organization, International Journal of Business Administration, Vol. 6, No. 5, pg. 75-81

Creyer, E. H. \& Ross, W. T. Jr. (1997). The influence of firm behavior on purchase intention: do consumers really care about business ethics? Journal of Consumer Marketing, Vol. 14, No. 6, pg. 421-432

Devinney, T. M. (2009). Is the Socially Responsible Corporation a Myth? The Good, the Bad, and the Ugly of Corporate Social Responsibility, Academy of Management Perspectives, Vol. 23, No. 2, pp. 44-56

Ellen, P. S.; Webb, D. J. \& Mohr, L. A. (2006). Building Corporate Associations: Consumer Attributions for Corporate Social Responsibility Programs? Journal of the Academy of Marketing Science, Vol. 34, No. 2, pg. 147-157.

FIFA

Available

from: http://www.fifa.com/marketinghighlights/brazil2013/social-responsibility/index.html Accessed: 2016-07-23 
Omazic, M. A.: Csr as a Prerequisite of Consumer Behavior in a Transitional Econo...

Fryzel, B. (2011). Building Stakeholder Relations and Corporate Social Responsibility. Palgrave MacMillan, ISBN: 978-0-230-27325-2, New York

Garriga, E. \& Melé, D. (2004). Corporate Social responsibility Theories: Mapping the Territory. Journal of Business Ethics, Vol. 53, No. 1-2, pg. 51-71

Godfrey, P. C. (2009) Research and Reviews Corporate Social Responsibility in Sport: An Overview and Key Issues, Journal of Sport Management, Vol. 23, No. 6, pg. 698716

Hopkins, M. (2003). The Planetary Bargain - Corporate Social Responsibility Matters, Earthscan, ISBN-13: 978-1853839788, London

Jain, P.; Vyas, V. \& Chalasani, D. P. S. (2016) Corporate Social Responsibility and Financial Performance in SMEs: A Structural Equation Modelling Approach, Global Business Review, Vol. 17, No. 3, pg. 630-653

Jones, P.; Comfort, D. \& Hillier, D. (2007). Marketing and corporate social responsibility within food stores, British Food Journal, Vol. 109, No. 8, pg. 582-593

Klein, J. \& Dawar, N. (2004). Corporate social responsibility and customers' attributions and brand evaluations in a product-harm crisis, International Journal of Research in Marketing, Vol. 21, No. 3, pg. 203-217

Kotler, P. \& Lee, N. (2005). Corporate Social Responsibility: Doing the Most Good for Your Company and Your Cause, Wiley \& Sons, ISBN: 978-0-471-47611-5, New York

Kumar, S. \& Tiwari, R. (2011). Corporate Social Responsibility: Insights into Contemporary Research, The IUP Journal of Corporate Governance, Vol. 10, No. 1, pg. $22-44$

Lau, N.; Makhanya, K. \& Trengrouse, P. (2004). The corporate social responsibility of sports organizations: The case of FIFA, $4^{\text {th }}$ ed., International Center for Sports Studies Lii, Y.-S. \& Lee, M. (2012). Doing Right Leads to Doing Well: When the Type of CSR and Reputation Interact to Affect Consumer Evaluations of the Firm, Journal of Business Ethics, Vol. 105, No. 1, pg. 69-81

Marin, L.; Ruiz, S. \& Rubio, A. (2008). The Role of Identity Salience in the Effects of Corporate Social Responsibility on Consumer Behavior, Journal of Business Ethics, Vol. 84, No. 1, pg. 65-78

Matten, D. \& Moon, J. (2008). "Implicit" and "explicit" CSR: A conceptual framework for a comparative understanding of corporate social responsibility. Academy of Management Review, Vol. 33, No. 2, pg. 404-424

Mohr, L. A. \& Webb, D. J. (2005). The Effects of Corporate Social Responsibility and Price on Consumer Responses, The Journal of Consumer Affairs, Vol. 39, No. 1, pg. 121-147

Mohr, L. A.; Webb, D. J. \& Harris, K. E. (2001). Do Consumers Expect Companies to be Socially Responsible? The Impact of Corporate Social Responsibility on Buying Behavior. The Journal of Consumer Affairs, Vol. 35, No. 1, pg. 45-72 
Nan, X. \& Heo, K. (2007). Consumer responses to corporate social responsibility (CSR) initiatives: Examining the role of brand-cause fit in cause-related marketing, Journal of Advertising, Vol. 36, No. 2, pg. 63-74

Nike (2016). Available from: http://www.fairlabor.org/affiliate/nike-inc Accessed: 2016-07-25

Omazić, M. A. (2008). Corporate social responsibility and corporate governance. In: D. Tipurić et al. (Eds.). Corporate governance, pg. 323-361 Sinergija, ISBN: 978-9536895-36-6, Zagreb

Orlitzky, M.; Schmidt, F. L. \& Rynes, S. L. (2003). Corporate Social and Financial Performance: A Meta-Analysis, Organization Studies, Vol. 24, No. 3, pg. 403-441 Osmanagić Bedenik, N. \& Labaš, D. (2011). Role of Corporate Social Responsibility (CSR) in business planning and practice of Croatian companies. Tržište, Vol. 23, No. 2, pg. 143-164

Podnar, K. \& Golub, U. (2007). CSR expectations: the focus of corporate marketing, Corporate Communications: An International Journal, Vol. 12, No. 4, pg. 326-340

Pomering, A. \& Dolnicar, S. (2008). Assessing the prerequisite of successful CSR implemntation: are consumers aware of CSR initiatives?, Journal of Business Ethics, Vol. 85, No. 2, pg. 285-301

Schiffman, L. G. \& Wisenblit, J. (2015). Consumer Behaviour, $11^{\text {th }}$ ed., Pearson, ISBN-13: 978-0132544368, New Jersey

Sen, S. \& Bhattacharya, C. B. (2001). Does Doing Good Always Lead to Doing Better? Consumer Reactions to Corporate Social Responsibility, Journal of Marketing Research, Vol. 38, No. 2, pg. 225-243

Sen, S.; Bhattacharya, C. B. \& Korschun, D. (2006). The Role of Corporate Social Responsibility in Strengthening Multiple Stakeholder Relationships: A Field Experiment, Journal of the Academy of Marketing Science, Vol. 34, No. 2, pg. 158166

Singh, J.; del Mar Garcia de los Salmones Sanchez, M. \& del Bosque, I. R. (2008). Understanding Corporate Social Responsibilityand Product Perceptions in Consumer Markets: A Cross-cultural Evaluation, Journal of Business Ethics, Vol. 80, No. 3, pg. 597-611

Smith, S. M. \& Alcorn, D. S. (1991). Cause marketing: a new direction in the marketing of corporate responsibility, Journal of Consumer Marketing, Vol. 8, No. 3, pg. 19-35. Tian, Z.; Wang, R. \& Yang, W. (2011). Consumer Responses to Corporate Social Responsibility (CSR) in China, Journal of Business Ethics, Vol. 101, No. 2, pg. 197212

UEFA (2016). Available from:

http://www.uefa.org/MultimediaFiles/Download/uefaorg/CaptainsofChange/02/24/62 132/2246232_DOWNLOAD.pdf Accessed: 2016-07-26

United Way (2016). Available from: https://secure.unitedway.org/pages/about-the-nflunited-way-partnership Accessed: 2016-07-23 
Omazic, M. A.: Csr as a Prerequisite of Consumer Behavior in a Transitional Econo...

Vogel, D. (2015). The Market for Virtue - The Potential and Limits of Corporate Social Responsibility. Brookings Institution Press, ISBN -13:978-0-8157-9076-1, Washington DC

Walker, M. \& Kent, A. (2009). Do Fans Care? Assessing the Influence of Corporate Social Responsibility on Consumer Attitudes in the Sport Industry, Journal of Sport Management, Vol. 23, No. 6, pg. 743-769

Webb, D. J. \& Mohr, L. A. (1998). A typology of consumer responses to cause-related marketing: From skeptics to socially concerned, Journal of Public Policy \& Marketing, Vol. 17, No. 2, pg. 226-238

Weber, M. (2008). The business case for corporate social responsibility: A companylevel measurement approach for CSR, European Management Journal, Vol. 26, No. 4, pg. 247-261

Wongpitch, S.; Minakan, N.; Powpaka, S. \& Laohavichien, T. (2016). Effect of corporate social responsibility motives on purchase intention model: An extension, Kasetsart Journal of Social Sciences, Vol. 37, No. 1, pg. 30-37 